\title{
Farmer networks and agrobiodiversity interventions: the unintended outcomes of intended change
}

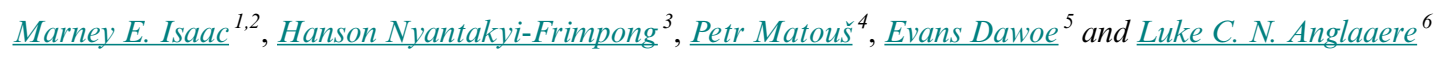

\begin{abstract}
Agroecosystem strategies to enhance agrobiodiversity can curb many of the negative impacts associated with current food production systems. With rising interest in agrobiodiversity and agroforestry as farming interventions that confer ecological and socioeconomic benefits, understanding the intended pathways of interventions is important for successful agroecological transformations. Yet, the patterns of agrobiodiversity introduction and adoption remain elusive. Drawing upon social network research from the regions of Ghana where cocoa (Theobroma cacao) is grown, we synthesize the relationships between agroforestry interventions, information networks, and the adoption of diversified agroecosystems. We illustrate middle-level patterns from independent studies in three regions of Ghana and nearly 500 farmer interviews. Strong structural indicators at the network level are linked to agrobiodiversity; farmers in larger, less dense information networks with ties to external organizations tend to have higher reported and measured agrobiodiversity. Remarkably, these trends were found in environmentally and socio-culturally different contexts in Ghana. However, these trends do not, in all cases, scale to the community level. For example, we did not observe any clear relationship between the density of community networks and the measures of agrobiodiversity at the community scale. This may be on account of the type of agrobiodiversity measure applied (above-ground biomass) to assess community-level outcomes. Selection of environmental attributes with meaningful spillover effects, such as pest management, would more likely uncover nontrivial network effects at the collective level. Our findings support that both innovation and cooperation are indispensable for successful agrobiodiversity interventions, and that networks can operate to overcome negative outcomes of agrobiodiversity. Based on these studies, we conclude that agrobiodiversity adoption via interventions and established farmer-to-farmer networks may trigger the formation of other, observation-based networks that draw in socially distant actors. Our research strategy of ex-post qualitative comparisons allowed for in-depth insight into the complexities of information networks and agrobiodiversity adoption but also generated new hypotheses on the role of social networks in diversified farming systems.
\end{abstract}

Key Words: agroecology; agroforestry; diversified agroecosystems; interventions; social-ecological systems; social network analysis

\section{INTRODUCTION}

In agricultural landscapes, implementing agroecological practices, such as enhancing associated and targeted biodiversity, can expand livelihood strategies, and reduce environmental and economic vulnerability (Abson et al. 2013, Bezner Kerr et al. 2019, Kozicka et al. 2020, Tamburini et al. 2020). With the rising interest in agrobiodiversity and agroforestry as farming interventions that confer ecological and socioeconomic benefits, understanding the intended pathway of interventions is important for successful agroecological transformations. Yet, the patterns of adoption and persistence of enhancing agrobiodiversity remain elusive. We know that the adoption of agrobiodiversity is often uneven within an agricultural landscape, and importantly, is shaped by influential macro- and micro-forces linked to institutions, the state, agricultural cooperatives, markets, and farmer-to-farmer knowledge sharing (Bacon et al. 2012, Isakson 2014, Labeyrie et al. 2021).

At the farm scale, motivation and resources to enhance on-farm agrobiodiversity can be drawn from formal sources, including extension services and NGOs, or informal sources, including neighbors and on-farm experimentation, or some combination thereof (Ali and Sharif 2012, Norton and Alwang 2020). Often, farmers are offered interventions from formal sources, such as public and private organizations or government agencies, that lead to higher agrobiodiversity, such as agroforestry practices, intercropping practices, or riparian or boundary buffers. These interventions are disseminated via various training frameworks, such as farmer field schools, or via resources such as the provisioning of seedlings (Tittonell et al. 2012, Cadger et al. 2016, Nyantakyi-Frimpong et al. 2019). Importantly, the adoption of new practices or techniques does not occur simultaneously within a community: those who participate in initial interventions represent a first wave or early adopters (sensu Rogers 2003), whereas others may strategically wait until their neighbors adopt first, for instance with new seeds (Krishnan and Patnam 2012) or with soil nutrient conservation practices (Gedikoglu et al. 2019).

The social transactions between actors involved in the agricultural landscape can influence the advancement or weakening of these sustainable agricultural practices (Isaac et al. 2007, Matouš et al. 2013, Levy and Lubell 2018) and therefore, such interactions are a central attribute to successful innovation systems (Klerkx et al. 2010, Wigboldus et al. 2016). Broadly, the agricultural extension literature points to the essential role of social networks in the transmission of new information from formal sources via diffusion and social learning (Genius et al. 2014, Wang et al. 2020). These social networks include bridging ties (with institutions) and bonding ties (generational, kinship, friendship, peer to peer; see Bodin and Crona 2009, Barnes et al. 2017). Bridging ties between

${ }^{1}$ Department of Physical and Environmental Sciences and Department of Global Development Studies, University of Toronto Scarborough, Canada, ${ }^{2}$ Department of Geography, University of Toronto, Canada, ${ }^{3}$ Department of Geography and the Environment, University of Denver, USA, ${ }^{4}$ University of Sydney, Australia, ${ }^{5}$ Agroforestry Department, Faculty of Renewable Natural Resources, Kwame Nkrumah University of Science and Technology, Ghana, ${ }^{6}$ CSIR-Forestry Research Institute of Ghana, Ghana 
Fig. 1. Networks are often used in the adoption of agrobiodiversity. Bridging ties between institutions and farmers introduce an intervention, which flows via bonding ties within established networks via farmer to farmer learning. Solid lines indicate cooperative farmer to farmer ties and dashed lines indicate innovative farmer to institutions ties. Filled circles are individual farmers and the empty circle represents an external actor.

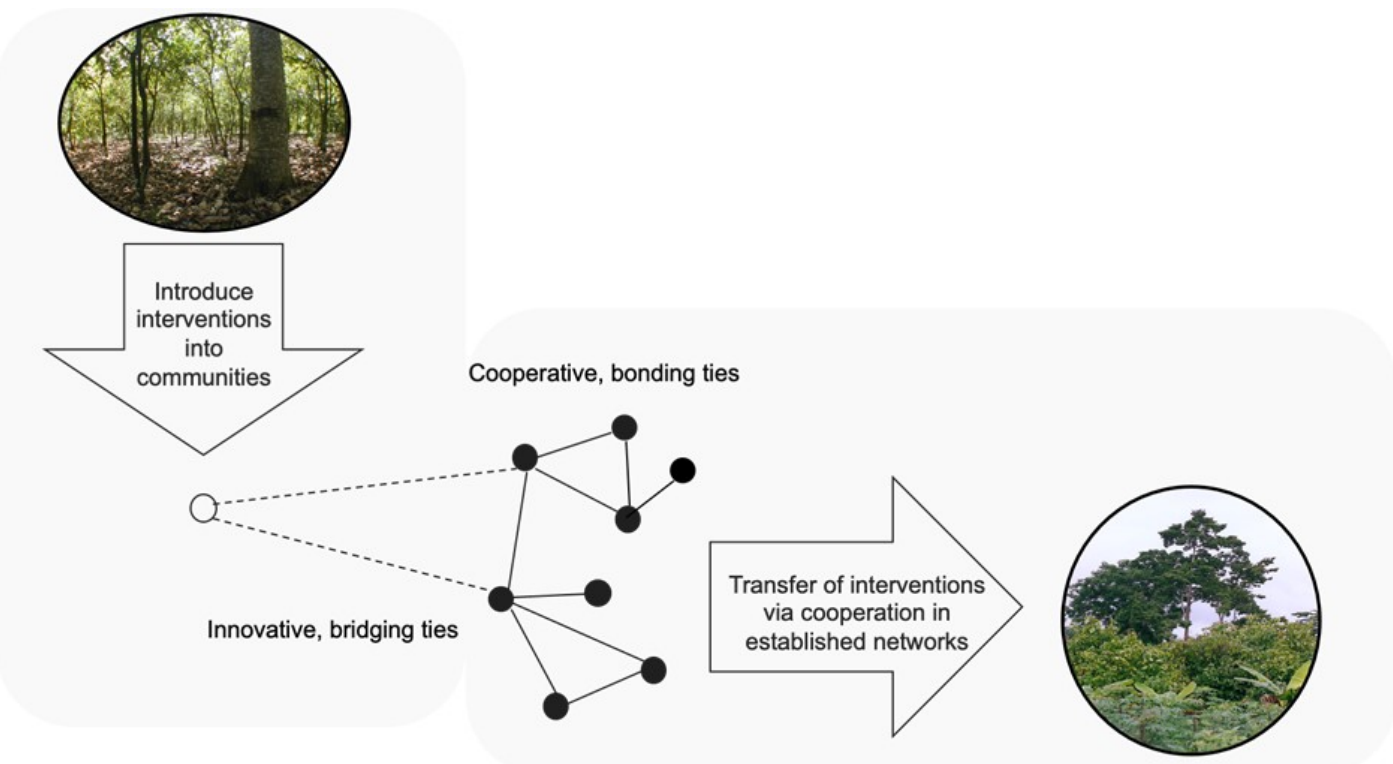

individuals and institutions and/or other external sources provide innovation in the form of novel interventions to enhance agrobiodiversity (Franzel and Scherr 2002), whereas bonding ties between farmers shape the adoption of agrobiodiversity via interaction and cooperation (Fig. 1). Essentially, these boundaryspanning individuals (see Matous and Wang 2019) act as information "kernels" in the community. The balance between the use of bridging ties to introduce new information and bonding ties to transfer key information, although recently explored (Wang et al. 2020), remains relatively unknown in the context of agrobiodiversity interventions.

The actual diffusion and durability of agrobiodiversity practices may be impacted by social network configurations, with various pathways of information transmission. The nodes (farmers) and links (information flow) form structural patterns (Bodin and Crona 2009). These patterns can be analyzed at the individual farmer "social neighborhood" scale, e.g., the immediate number of other nodes a farmer is directly connected to, or at the farming community scale, encompassing more distal network density or centrality measures. Each topology of a network may differentially relate to the overall adoption of agrobiodiversity. These networks may also interface with endogenous on-farm experimentation and observation with other, unintentional consequences for networks.

In this paper, we leverage the relatively rare opportunity to integrate a larger number of different studies of the same agrobiodiversity adoption - the transformation of monocultures to agroforestry systems - with a consistent definition of network nodes and links. Most empirical research on social-ecological networks has been engaged in disconnected case studies, making it problematic to derive broader conclusions and recommendations that could reach beyond the specifics of each context (Bodin et al. 2019). Although there is a long history of longitudinal work in anthropology (e.g., Whitehead 2002, Li 2014), development studies (e.g., Turner 2012), and human-environment geography (Tiffen et al. 1994, Mortimore and Tiffen 2004), it is rare to find longitudinal analysis in social networks and agrobiodiversity, although it is clearly important for policy. Here, we use a research strategy of multiple cases studies (sensu Rihoux 2006) in order to collect in-depth insight and capture complexities but also produce generalizations and generate new hypotheses.

Drawing upon social network research from the cocoa-growing regions of Ghana, we illustrate the relationship between network topologies and the presence of shade trees and crop diversity in agroforestry systems. Drawing on six independent studies in three regions of Ghana (Fig. 2) and nearly 500 farmer interviews over 10 years, we describe the structure of information networks on agrobiodiversity interventions and the consequences of networks on the diversification of agroecosystems. These case studies use both standard techniques and advanced modeling approaches to illustrate if and when networks matter for agrobiodiversity. We present middle-level patterns among studies from ecologically, historically, socially, and culturally different regions, and draw upon farmer descriptions of information acquisition and transfer. We then discuss network outcomes at the individual and collective levels, we describe the balance between innovation and cooperation for successful agrobiodiversity interventions, and we explore whether these information networks result in other social phenomena. In doing so, these findings provide insight into the structural characteristics and environment outcomes of interventions for the transformation pathway to agroecosystem diversification. 
Table 1. Overview of field studies on agroforestry interventions from 2006 to 2016 in the cocoa-growing region of Ghana.*

\begin{tabular}{|c|c|c|c|c|c|c|}
\hline $\begin{array}{l}\text { Year(s) of } \\
\text { data } \\
\text { collection }\end{array}$ & Sample size & $\begin{array}{l}\text { Geographical } \\
\text { information }\end{array}$ & $\begin{array}{l}\text { Agrobiodiversity } \\
\text { intervention } \\
\text { (initial year) }\end{array}$ & $\begin{array}{l}\text { Method of network data } \\
\text { collection }\end{array}$ & Network scale & $\begin{array}{l}\text { Type (and method) of } \\
\text { agrobiodiversity data }\end{array}$ \\
\hline 2006 & 89 farmers & $\begin{array}{l}4 \text { communities in } 1 \\
\text { region }\end{array}$ & $\begin{array}{l}\text { NGO } \\
\text { agroforestry } \\
\text { program (1999) }\end{array}$ & In-depth interviews & $\begin{array}{l}\text { Community } \\
\text { networks }\end{array}$ & None \\
\hline $2006 \& 2008$ & 25 farmers & $\begin{array}{l}2 \text { communities in } 2 \\
\text { regions }\end{array}$ & $\begin{array}{l}\text { NGO and } \\
\text { government } \\
\text { agroforestry } \\
\text { program (1999) }\end{array}$ & Semi-structured interviews & Ego networks & $\begin{array}{l}\text { Shade tree diversity (reported as } \\
\text { species richness per farm) }\end{array}$ \\
\hline 2011 & 44 farmers & $\begin{array}{l}3 \text { communities in } 1 \\
\text { region }\end{array}$ & $\begin{array}{l}\text { NGO and } \\
\text { university } \\
\text { agroforestry } \\
\text { program (2006) }\end{array}$ & In-depth interviews & $\begin{array}{l}\text { Community and } \\
\text { ego networks }\end{array}$ & $\begin{array}{l}\text { Agroforestry practices (reported } \\
\text { as type and number of } \\
\text { agroforestry and farm practices) }\end{array}$ \\
\hline 2013 & 131 farmers & $\begin{array}{l}6 \text { communities in } 2 \\
\text { regions }\end{array}$ & $\begin{array}{l}\text { NGO, university, } \\
\text { and government } \\
\text { agroforestry } \\
\text { program (2006) }\end{array}$ & Questionnaire & Ego networks & $\begin{array}{l}\text { Crop diversification (reported as } \\
\text { crop richness per farm) }\end{array}$ \\
\hline $2013 \& 2014$ & 116 farmers & $\begin{array}{l}3 \text { communities in } 1 \\
\text { region }\end{array}$ & $\begin{array}{l}\text { NGO } \\
\text { agroforestry } \\
\text { program (2006) }\end{array}$ & Questionnaire & Ego networks & $\begin{array}{l}\text { Land use type and size } \\
\text { (measured in-field as land use } \\
\text { type and size in ha) }\end{array}$ \\
\hline 2016 & 104 farmers & $\begin{array}{l}5 \text { communities in } 1 \\
\text { region }\end{array}$ & $\begin{array}{l}\text { Private and } \\
\text { cooperative } \\
\text { agroforestry } \\
\text { program }(2011) \\
\end{array}$ & $\begin{array}{l}\text { Questionnaire and semi- } \\
\text { structured interviews }\end{array}$ & $\begin{array}{l}\text { Community and } \\
\text { ego networks }\end{array}$ & $\begin{array}{l}\text { Above-ground biomass } \\
\text { (measured in field with } \\
\text { allometric equations based on } \\
\text { shade tree height and diameter) }\end{array}$ \\
\hline
\end{tabular}

Fig. 2. Map of Ghana highlighting the study districts and regions. Our synthesis draws on farmer experiences from different parts of the country, spanning five districts in three regions (Western Region, Brong-Ahafo Region, and Ashanti Region). Note: as of October 2020, Ghana's regional demarcations have changed; figure depicts regional demarcations at the time of fieldwork from 2006 to 2016.

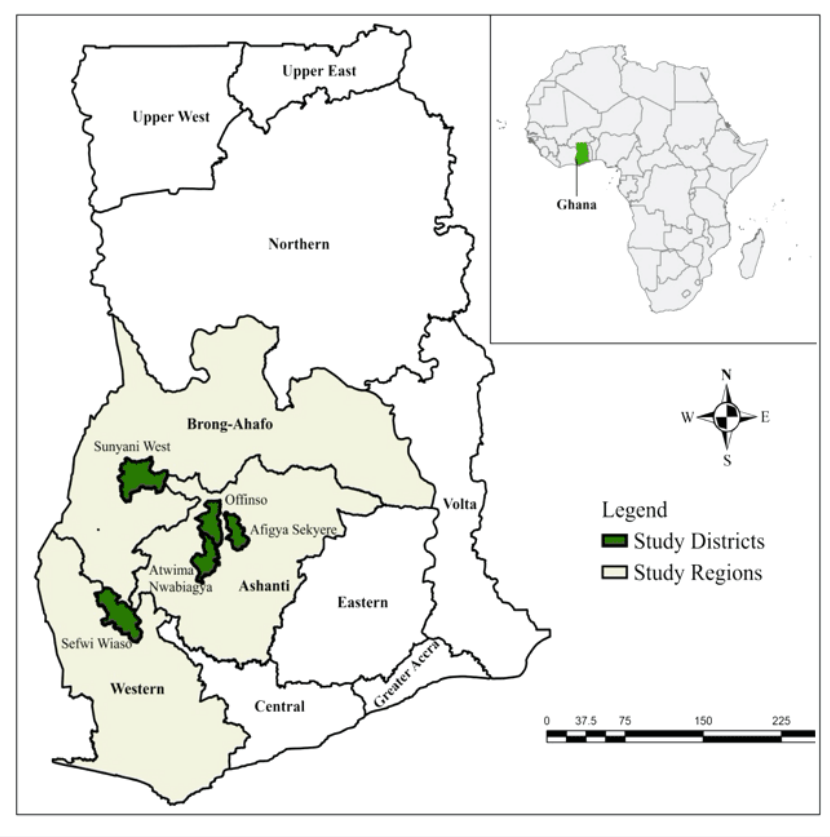

The case study: cocoa agroforestry interventions in Ghana

Cocoa (Theobroma cacao L.) is a perennial crop cultivated in the forest ecological zones of West Africa and other parts of the world. We focus on cocoa agroecosystem management in Ghana, West Africa. Ghana is the second highest cocoa-producing country in the world, after Côte d'Ivoire (Ameyaw et al. 2018). Cocoa is the country's second largest foreign exchange earner and represents about $21.5 \%$ of gross domestic product (GDP; Ghana Cocoa Board 2020). More than 800,000 farming households in Ghana depend on cocoa for their livelihoods (Ghana Cocoa Board 2020). The most productive cocoa-growing regions in the country are Ashanti, Brong-Ahafo, Central, Eastern, Western, and Volta regions.

Agroecosystem management is extremely important for the longterm sustainability of Ghana's cocoa production. Uncertain climatic conditions, including precipitation and temperature variability, make cocoa cultivation in Ghana very risky (Bunn et al. 2019, Afriyie-Kraftet al. 2020). Cocoa generally requires temperatures ranging between $21^{\circ} \mathrm{C}$ and $23{ }^{\circ} \mathrm{C}$, and annual rainfall between 1000 and $2500 \mathrm{~mm}$ to achieve optimum yields (Ameyaw et al. 2018). Thus, research continues to show that the adverse impacts of climate change would have negative consequences for cocoa production in the country (Bunn et al. 2019, Amfo and Ali 2020). Cocoa cultivation is also a major driver of deforestation and forest degradation across the country's high forest zone (Asare 2019, Tropenbos International Ghana 2019). In most of Ghana's cocoa-growing regions, the conversion of intact forest for cocoa cultivation has increased from $2.8 \%$ per year from 1986 to 2000 , to $6.1 \%$ from 2000 to 2011 (Kroeger et al. 2017). Intensified cocoa production has led to reduced forest cover, biodiversity loss, and increased carbon emissions, but also soil degradation and contamination from pesticides at the farm 
Table 2. Summary of findings including agrobiodiversity practice after an intervention, data scope, network scale, and network signature that supports agrobiodiversity.

\begin{tabular}{|c|c|c|c|}
\hline $\begin{array}{l}\text { Agrobiodiversity metric } \\
\text { (after interventions) }\end{array}$ & Data scope & Network scale & Network signature supporting agrobiodiversity \\
\hline Shade tree diversity & $\begin{array}{l}25 \text { farmers in } 2 \\
\text { communities }\end{array}$ & Ego network & $\begin{array}{l}\text { Higher network efficiency was significantly } \\
\text { correlated with higher reported shade tree } \\
\text { diversity. }\end{array}$ \\
\hline Agroforestry practices & $\begin{array}{l}44 \text { farmers in } 3 \\
\text { communities }\end{array}$ & $\begin{array}{l}\text { Community network and ego } \\
\text { networks }\end{array}$ & $\begin{array}{l}\text { Farmers in brokerage positions in the network } \\
\text { were more likely to adopt diversified practices. }\end{array}$ \\
\hline Shade tree and crop diversity & $\begin{array}{l}131 \text { farmers in } 6 \\
\text { communities }\end{array}$ & Ego network & $\begin{array}{l}\text { Farmers with larger network size and number of } \\
\text { ties to organizations were more likely to report } \\
\text { higher shade tree and crop diversity. }\end{array}$ \\
\hline Land use diversity including agroforestry & $\begin{array}{l}116 \text { farmers in } 3 \\
\text { communities }\end{array}$ & Ego network & $\begin{array}{l}\text { Farmers with higher number of ties to } \\
\text { organizations had greater land use diversity. }\end{array}$ \\
\hline $\begin{array}{l}\text { Shade tree abundance and biomass } \\
\text { accumulation }\end{array}$ & $\begin{array}{l}104 \text { farmers in } 5 \\
\text { communities }\end{array}$ & Community and ego networks & $\begin{array}{l}\text { Farmers with higher network indegree at the ego } \\
\text { scale and higher } 2 \text {-star parameter at the } \\
\text { community scale had higher biomass } \\
\text { accumulation from adoption of shade trees. }\end{array}$ \\
\hline
\end{tabular}

scale (Takyi et al. 2019, Tropenbos International Ghana 2019). Reduced forest extents are suggested to have dire implications for biodiversity and regional climate patterns, thus affecting climate suitability for cocoa cultivation and the livelihoods of cocoa smallholders (Amfo and Ali 2020). Several factors account for relatively low yields, including low soil fertility, poor shade management, increased pest and disease pressure, lack of quality planting material, aging farms, and inadequate agriculture extension service delivery (Abdulai et al. 2020, Leitão 2020).

Given these challenges, local and international NGOs, universities, the government of Ghana, and multinational agribusiness organizations have introduced several agricultural innovations geared toward boosting productivity and minimizing the environmental footprint of cocoa production (see Table 1). These initiatives focus on enhancing rural livelihoods and environmental protection through the implementation of agroforestry practices via the provisioning of seedlings and knowledge. These not-for-profit and public sector programs are paired with national programs such as Ghana Cocoa Forest REDD+ Program (GCFRP); the National Climate-Smart Agriculture and Food Security Action Plan; the Ghana Cocoa and Forest Initiative National Implementation Plan; the Ghana Forest Investment Program (GFIP); and the National Cocoa Rehabilitation Programme (see for example Kroeger et al. 2017, Ameyaw et al. 2018, Ghana Cocoa Board 2020). Major cocoabuying companies, such as ECOM, Kuapa, Mondelēz, and Touton, also have their own sustainability interventions, some labeled as climate-smart cocoa projects, to enhance biodiversity and land use diversification (Nyantakyi-Frimpong et al. 2019, Nasser et al. 2020).

Cumulatively, these schemes and extension activities support the conversion of cocoa grown in monocultures to cocoa grown under diverse shade conditions in agroforestry systems. Generally, cocoa agroforestry systems in the studied regions are mostly mixed stands of cocoa with variable proportions of naturally generated or planted shade trees such as Terminalia superba Engl. \& Diels, Triplochiton scleroxylon K. Schum., Alstonia boonei de Wild, and Ceiba pentandra (L.) Gaertn. Fruit trees such as orange (Citrus sinensis (L.) Osbeck), Avocado (Persea americana), and mango
(Mangifera indica L.) may be planted for shade, food, and other purposes (Sauvadet et al. 2020). In addition, in younger farms, food crops such as cocoyam or plantain/bananas are included for temporal shade in the early phase of plantation establishment. Evidence supports a suite of ecosystem functions derived in these agroforestry systems, including yield stability, climate regulation, disease mitigation, localized soil fertility, and the production of food (Asare et al. 2014, Abdulai et al. 2018, Isaac and Borden 2019, Borden et al. 2020).

\section{METHODS}

In this paper, we synthesize over 10 years of research examining how farmer social networks shape the adoption and diffusion of agroforestry practices after interventions in cocoa systems in Ghana (Table 1). Between 2006 and 2016, we conducted fieldwork in three regions of Ghana (Fig. 2) that are among the highest cocoa production sites in the country. These regions also have distinct ecological contexts, as well as social and cultural dynamics that are important for farmer knowledge exchanges and agrobiodiversity. The three regions are the following: (1) the Ashanti Region, a moist semi-deciduous forest ecological zone with a major and minor rainy season; (2) the Brong-Ahafo Region, a moist semi-deciduous forest, transitional and Guinea Savanna woodland zone, also with two rainy seasons; and (3) the Western Region, which is located in the high forest zone and wettest part of Ghana, with two rainy seasons, abundant vegetation and tree cover relative to other regions. Each region has distinct major ethnic groups with social norms that shape farming resource access and control, including land tenure (Kasanga and Kortey 2001). The Brong-Ahafo Region also has a relatively higher number of internal migrant farmers engaged in cocoa production compared to the other two study regions. Moreover, the history of cocoa cultivation is different among the three regions. The Ashanti Region opened as a cocoa frontier in the 1910s, the BrongAhafo Region in the 1940s, and the Western Region in the 1960s (Benneh 1988, Knudsen and Agergaard 2015).

Across all studies, we gathered network data with name-generator and snowball techniques through semi-structured interviews at minimum five years after an agroforestry intervention (see Table 1). All smallholder and family farms contained cocoa production, 
varied in their degree of adoption of shade trees and subsistence crops, and range in size from 2 to 5 ha in most studies up to approximately 12 ha in one study. The primary network question posed to obtain this list of individuals or organizations (NGOs, local institutions, universities, government agencies, private sector) was, "Whom do you contact to get information on the introduction and management of agrobiodiversity on your cocoa farm?" In all studies, this observed network data was coded as binary variables, i.e., the presence or absence of a unidirectional tie, and entered into a name-based adjacency matrix. Depending on the study and the extent of the network data, matrices were analyzed at either the ego level, that is, the personal network composed of the individual farmer and their contacts, or the whole community level, composed of all identified actors until no new actors are mentioned. In all studies, we used this observed network data with two different statistical approaches: standard network analysis and exponential random graph models (ERGM). Types and methods of environmental data collection varied between studies, ranging from measured field agrobiodiversity, land use diversification, and carbon storage to reported agrobiodiversity. All studies included here received approval from the University of Toronto Research Ethics Board.

\section{RESULTS AND DISCUSSION}

\section{Agrobiodiversity interventions and the structure of information- sharing networks}

The multi-community approach consistently showed a high density of information ties among a small group of farmers, indicating a core-periphery structure in sharing agroforestry practices (Isaac et al. 2007). This core-periphery structure was significant in all four communities in this study. This type of centralized network structure was supported by findings in five communities a decade later; Nyantakyi-Frimpong et al. (2019) showed positive and significant estimates of the 2-star parameter using ERGMs within the community networks, which suggests a centering of information ties on the most popular advisers. This is not uncommon as other work has shown that rural development programs and interventions may result in unequally distributed responsibilities and benefits, which could increase the centrality of involved individuals and potentially elevate core community members (Heß et al. 2021).

Community and ego network structures and the extent of agrobiodiversity practices are summarized across five studies (Table 2). Ego network indegree, or the number of ties, was positively correlated with biomass accumulation from the adoption of agroforestry practices (Nyantakyi-Frimpong et al. 2019). In support of this finding, farmers embedded in larger networks, with direct ties to organizations, reported higher levels of agrobiodiversity and adoption of agroecological practice (Cadger et al. 2016). Furthermore, farmers in boundary-spanning or brokerage roles who connected socially and geographically distant farmers tended to adopt agroforestry practices (Isaac et al. 2014). Farmers in more efficient information networks, created by replacing farmer ties with ties to organizations, reported higher on-farm agrobiodiversity (Isaac 2012). Scaling out from field to farm, the number of farmer ties to organizations was also positively correlated to the diversity of land use types, including agroforestry, fallow systems, and plantations (Isaac and Matous 2017). The role of ties to organizations is similarly important in all studies yet the role of overall network size is less consistent. This may be attributed to the environmental measures in each study. For instance, Isaac (2012) measured reported shade tree diversity exclusively, whereas Cadger et al. (2016) determined information networks for both shade trees and food crops, the latter of which may have influenced the significant role of network size given that food crop networks tended to be larger (Cadger et al. 2016).

Broadly, networks tend to form around people who have been supported by local organizations and have adopted agroforestry, probably as a result of such support. Moreover, the adoption of agroforestry practices also tended to be related to other proenvironmental practices; as one farmer stated, "I learned the importance of trees for shade from my parents and from the NGO, but through my own experience I became aware that some other crops do better under shade" (2014). Interestingly, despite the distinctiveness in the ecological, historical, social, and cultural characteristics of the study regions, we show these consistent results based on different studies.

\section{Scaling to the community level and the role of environmental spillovers}

Drawing a link between networks and agrobiodiversity outcomes was possible only at the ego network level within our studies and it is important to emphasize that network mechanisms for community-level outcomes may be quite different. Indeed, Nyantakyi-Frimpong et al. (2019) did not find any relationship between community-level outcomes and collective network structure that would parallel those at the individual level. Using ERGMs among five whole networks, there was no indication that larger, denser, or more clustered communities would have different levels of biomass from the adoption of agroforestry than communities that were smaller or sparser, or networks that have more evenly distributed relationships among the farmers.

Nevertheless, although we did not find any signature of scalability of our results from individual to collective, farmers mentioned several positive community effects related to adopting agroforestry, including increased collaboration and resource sharing among farmers (Table 3). For example, in explaining the community-level social outcomes of agroforestry, one participant mentioned that "I can say that the project has brought unity among the participating farmers, which is helpful if you want to exchange information and other resources" (2016). Another farmer shared an experience by saying "at the community level, it has led to increased collaboration among farmers" (2016).

It is important to note that collective measures of agrobiodiversity applied in these studies were aggregates of individual-level measures, yet conceptually and ecologically, the agrobiodiversity metric may have different relevance at the individual and collective levels. Individual-level benefits from adopting agroforestry, such as diversified crop portfolios or microclimate regulation, are conferred at the farm scale. However, many benefits from agrobiodiversity effects on, say, integrated pest management occur via environmental spillovers. In this scenario, environmental nodes become ecologically connected and thus create dependencies between farms, for example via pest regulation. It is the collective landscape that benefits from agrobiodiversity effects such as overall decreased pest levels in the local area that may be missed by research focused on individual 
farm units. From individual qualitative accounts available to us, it appears that the opportunity for community-level coordination to leverage such collective-level benefits was not really utilized in the studied locations, and in fact farmers tended to complain about increases rather than decreases of pest levels on their own plot. What we failed to gather data on is how agroforestry adoption by other farmers affects pest perceptions of the focal farmer or overall pest levels in the area. Furthermore, diversity itself can, of course, be assessed at different scales, and agrobiodiversity within a community can be increased not only by increasing species diversity within each farmer's plot, but also by cultivating different plants on plots of neighboring smallholder and family farms.

Table 3. Farmer-identified positive and negative outcomes of agrobiodiversity interventions. Presented are the top outcomes from the introduction of agroforestry practices into cocoa systems.

\begin{tabular}{ll}
\hline \hline Themes & Frequency of codes, in descending order $(n=104$ farmers $)$ \\
\hline Positive & 1. More shade for cocoa trees $(n=90)$ \\
Outcomes & 2. Increased cocoa yield $(n=63)$ \\
& 3. Improved soil health $(n=59)$ \\
4. Increased farm income $(n=33)$ \\
5. Suppressed weed growth and pest infestation $(n=17)$ \\
6. Increased community awareness about climate change $(n=$ \\
17) \\
7. Improved farmer collaboration, knowledge exchanges $(n=$ \\
15) \\
8. Improved subsistence crop production (e.g., maize and yam) \\
( $n=9)$ \\
9. Rainfall has now become more frequent $(n=1)$
\end{tabular}

Negative 1. Labor-intensive in terms of weeding and pruning $(n=47)$ Outcomes 2. The emergence of new crop pests $(n=24)$

Data source: Fieldwork in 2016.

To further advance empirical study of relationships between networks and their environmental outcomes and to be able to provide policy recommendations that are beneficial at the landscape level, attention to truly collective-level agrobiodiversity measures, not just aggregates from individual level, and their system-level outcomes (that will, importantly, include environmental spillovers) is required. A better understanding of such collective-level issues should be high on the research agenda, especially for network scholars interested in social-ecological systems. So far much of the empirical socio-environmental network research, including that of the studies this paper is based on, has been focused on nodes and their aggregate measures rather than truly system-level (i.e., network-level) socio-environmental network drivers and consequences.

Generating new hypotheses: using existing networks to address negative outcomes of agrobiodiversity interventions

Although farmers observed many positive individual outcomes of adopting agrobiodiversity across most of the studies, in the multi-community agroforestry intervention studies (Isaac and Matous 2017, Nyantakyi-Frimpong et al. 2019), farmers also highlighted recurring negative individual outcomes, including those related to increased labor, pests, and disease (Table 3). Among these concerns, the most noteworthy was new pest infestations, as well as increased labor needs for weeding and pruning. As one farmer mentioned, "the agroforestry project has also affected me negatively. I now have to pay for the higher cost of labor to weed and prune the trees so that they don't overshadow my cocoa crops. That is an added cost. I have also seen more crop pest since the addition of the new trees" (2016). Another farmer echoed a similar sentiment, with a concern that "for the negative aspects, I can mention two experiences. First, because of the trees, there is increased cost of labor for weeding and pruning. That is an added cost I have to pay, which was not the case previously. Second, I have seen higher crop pest infestation and I think that is because of the new trees" (2016). Existing studies on agroforestry provide mixed evidence on labor intensity. Some studies have found agroforestry to be labor intensive (Franzel et al. 2001, Vanlauwe and Giller 2006), but others do not, suggesting that a weaker linkage between agroforestry and labor needs is attributed to field size (Ajayi et al. 2009). In one of the Ghanaian studies being reported here, the average field size was 12 ha (though somewhat skewed in certain regions by larger land owners; Nyantakyi-Frimpong et al. 2019), which could partly explain farmer concerns about labor intensity for weeding and pruning shade trees.

There are several ways in which network collaboration within existing social networks could be harnessed to address issues of increased labor demands and pest infestations. For example, existing networks could be used to enhance reciprocal labor exchanges for weeding and pruning. There is already a long history of the existence of such reciprocal labor exchange groups in Ghana's cocoa-growing regions (Porter and Lyon 2006). Farmers participating in these exchange groups, locally called nnoboa, arrange to provide labor in turn in each other's farms (Boon and Anuga 2019). Similarly, existing farmer social networks, collaborative groups, and rural cooperatives could also be harnessed to foster information sharing on integrated pest management (Borkhani et al. 2013, Lescourret et al. 2015). This approach has been successfully used in many African farming settings, including in Mali (Stemerding et al. 2002), Malawi (Nyantakyi-Frimpong et al. 2017, Kpienbaareh et al. 2020), and Uganda (Bonabana-Wabbi 2002).

\section{Generating new hypotheses: unintended effects of} agrobiodiversity interventions on network patterns

Although our qualitative comparative analysis among case studies was developed ex post, it did allow for some formalization of social features but also exposed previously undetected phenomena. Among all the case studies, farmer network size, density, and composition were distinct for farmers who were associated with NGO programs, farmer cooperatives, and/or other non-structured groups for extension services. For instance, development project-affiliated farmers were embedded in larger networks and had non-affiliated farmers within their networks; these NGO-affiliated farmers, with access to different information sources, also tended to report adopting agroecological practices more frequently than those not affiliated with an NGO (Cadger et al. 2016). Similarly, producers in "efficient networks" (sensu Burt 2007) with ties to organizations were likely to be positively correlated to higher reported on-farm agrobiodiversity (Isaac 2012). Farmers who were not highly sought for information on agrobiodiversity practices also tended not to seek information from institutions or other formal sources 
Fig. 3. Two network types are functioning in agrobiodiversity adoption: established networks linked to institutions and emergent networks formed by observation and advice seeking. Agrobiodiversity interventions, such as the transformation of cocoa monocultures to cocoa agroforestry systems with the inclusion of shade trees, can be introduced via boundary-spanning farmers and disseminated to the larger community via established networks, and farmer-to-farmer learning. New information networks can also emerge from agrobiodiversity interventions via observation of successful farming practices thus including socially distant farmers.

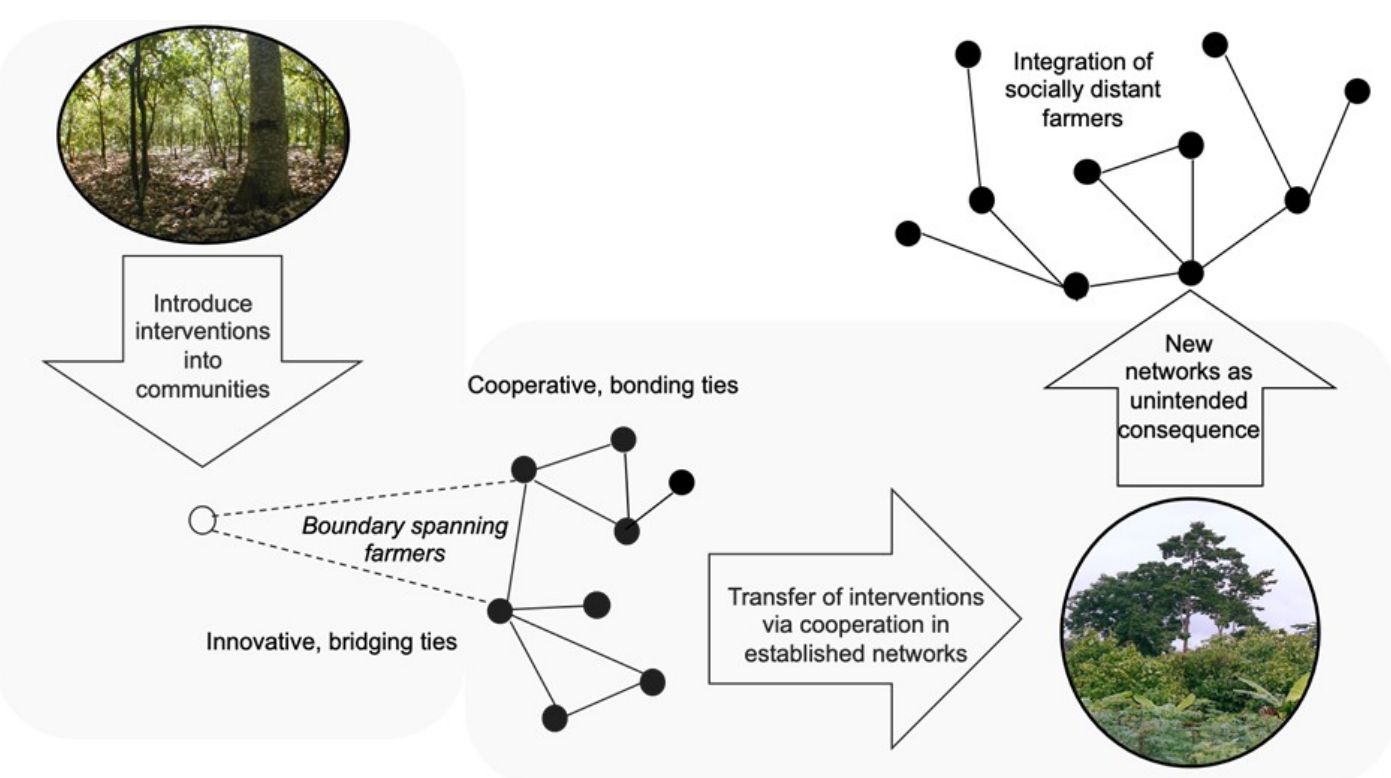

of information but rather reported observations of neighboring farmers (Isaac et al. 2007). These consistent findings on organizational ties and agrobiodiversity interventions suggest that these initial points of introduction of agroforestry are functioning as intended, to promote the recommended practices (see Fig. 1).

The established trajectory of early and late adopters in the diffusion of innovation has recently been expanded to include more complex social processes (see for example Klerkx et al. 2012). Those who participate in initial interventions, indeed, represent a first wave of adopters, creating a network with generalizable structure, centering around a core, e.g., knowledge clustering (Joffre et al. 2019), and with ties to institutions. Simultaneously though, findings from our case studies suggest that while these agrobiodiversity interventions are being adopted, new emergent networks are taking shape, based on observation of farming practices and the seeking of advice unrelated to the initial wave of the agrobiodiversity intervention (Fig. 3). These emerging, second wave, networks we observed are not based on the initial agrobiodiversity intervention, but as an unintended consequence of the first wave of adoption of agrobiodiversity. For instance, farmers who are not targeted by extension services or NGOs, and perhaps do not even know about any specific agrobiodiversity practices or programs, observe farms with these new practices, which subsequently enables new ties. These new advice ties may not necessarily be about the initial practice, but rather some other important agricultural practice. For instance, migrant farmers transferred information on how to mitigate soil water stress in networks formed via new ties on observing agroforestry practices (Isaac et al. 2014) and female farmers transferred information on crop diversity in networks formed around agroforestry practices (Cadger et al. 2016). Importantly, we argue that these new ties in subsequent networks tend to draw in socially and geographically distant farmers, who otherwise may have been excluded. Our conceptualization of established and emerging networks supports the multiplicity in information gathering, exchange, and action (Leeuwis and Aarts 2011).

More research is needed to better understand these emergent networks. To what degree do agrobiodiversity practices by farmers in emergent networks differ from originally introduced interventions? Are new innovations added to the already successful practices observed from those who received the original interventions? What specific types of agrobiodiversity interventions, e.g., tree planting only, trees plus subsistence crops, or trees and soil conservation, lead to the formation of these emergent networks? Although these established and emergent networks presumably overlap, it is possibly a disservice to our understanding of successful agrobiodiversity interventions to assume that there is a singular functioning network for the dissemination of agrobiodiversity practices.

\section{CONCLUSIONS}

Strong structural indicators within community and ego networks are evident, and are linked to diversification of agroecosystems. In particular, from the approximately 500 farmers interviewed among these case studies, farmers with larger, less dense information networks with ties to external actors tend to have higher reported or measured agrobiodiversity. These findings 
were remarkably consistent despite the fact that the evidence comes from three Ghanaian regions with different environmental, historical, social, and cultural dynamics. Furthermore, careful selection and development of environmental metrics that include spillovers between individual farming plots is needed to meaningfully examine the network drivers of agrobiodiversity at the collective level. Finally, both innovation and cooperation are indispensable to the successful introduction and adoption of agrobiodiversity. We provide new conceptualizations of the dynamics of innovation and cooperation that distinguish between established networks formed around boundary-spanning farmers and emergent networks formed around observations of successful practices that draw in more socially and geographically distant farmers.

Agriculture extension delivery, especially in Africa, has been criticized for its top-down approach and its exclusion of key social-political factors (Cook et al. 2021). As the case studies demonstrate here, however, networks tend to form around people who have been supported by organizations, including NGOs and government agencies with extension mandates. To achieve greater equity in advisory services, the focus should be not only on farmerto-farmer knowledge sharing, but also on the formation of second wave networks. We show here that social networks act as a strong mechanism for farmers to enhance agrobiodiversity, beyond those targeted for training and boundary-spanning positions.

Responses to this article can be read online at: https://www.ecologyandsociety.org/issues/responses. php/12734

\section{Acknowledgments:}

The authors sincerely thank all study participants who took part in these studies. We thank anonymous journal reviewers for their insights. This article is based on fieldwork conducted with funding from the International Development Research Centre to M.E.I. and L.C.N.A, the Canada Research Chairs program, the Centre for Agroecosystems Research, and a Social Sciences and Humanities Research Council of Canada Insight Development Grant to M.E.I.

\section{Data Availability:}

All data is from previously published articles by the authors (see Table 1).

\section{LITERATURE CITED}

Abdulai, I., M. P. Hoffmann, L. Jassogne, R. Asare, S. Graefe, H. H. Tao, and R. P. Rötter. 2020. Variations in yield gaps of smallholder cocoa systems and the main determining factors along a climate gradient in Ghana. Agricultural Systems 181:102812. https://doi.org/10.1016/j.agsy.2020.102812

Abdulai, I., L. Jassogne, S. Graefe, R. Asare, P. V. Asten, P. Läderach, and P. Vaast. 2018. Characterization of cocoa production, income diversification and shade tree management along a climate gradient in Ghana. PLoS ONE 13(4):e0195777. https://doi.org/10.1371/journal.pone.0195777

Abson, D. J., E. D. G. Fraser, and T. G. Benton. 2013. Landscape diversity and the resilience of agricultural returns: a portfolio analysis of land-use patterns and economic returns from lowland agriculture. Agriculture \& Food Security 2:2. https://doi. org/10.1186/2048-7010-2-2

Afriyie-Kraft, L., A. Zabel, and L. Damnyag. 2020. Adaptation strategies of Ghanaian cocoa farmers under a changing climate. Forest Policy and Economics 113:102115. https://doi. org/10.1016/j.forpol.2020.102115

Ajayi, O. C., F. K. Akinnifesi, G. Sileshi, and W. Kanjipite. 2009. Labour inputs and financial profitability of conventional and agroforestry-based soil fertility management practices in Zambia. Agrekon 48(3):276-292. https://doi.org/10.1080/03031853.2009.9523827

Ali, A., and M. Sharif. 2012. Impact of farmer field schools on adoption of integrated pest management practices among cotton farmers in Pakistan. Journal of the Asia Pacific Economy 17 (3):498-513. https://doi.org/10.1080/13547860.2012.694706

Ameyaw, L. K., G. J. Ettl, K. Leissle, and G. J. Anim-Kwapong. 2018. Cocoa and climate change: insights from smallholder cocoa producers in Ghana regarding challenges in implementing climate change mitigation strategies. Forests 9(12):742. https://doi. org/10.3390/f9120742

Amfo, B., and E. B. Ali. 2020. Climate change coping and adaptation strategies: how do cocoa farmers in Ghana diversify farm income? Forest Policy and Economics 119:102265. https:// doi.org/10.1016/i.forpol.2020.102265

Asare, R. 2019. The nexus between cocoa production and deforestation. Grain De Sel 78:26-27. [online] URL: https:// cgspace.cgiar.org/handle/10568/108991

Asare, R., V. Afari-Sefa, Y. Osei-Owusu, and O. Pabi. 2014. Cocoa agroforestry for increasing forest connectivity in a fragmented landscape in Ghana. Agroforestry Systems 88:1143-1156. https:// doi.org/10.1007/s10457-014-9688-3

Bacon, C. M., C. Getz, S. Kraus, M. Montenegro, and K. Holland. 2012. The social dimensions of sustainability and change in diversified farming systems. Ecology and Society 17(4):41. https:// doi.org/10.5751/ES-05226-170441

Barnes, M. L., Ö. Bodin, A. M. Guerrero, R. J. McAllister, S. M. Alexander, and G. Robins. 2017. The social structural foundations of adaptation and transformation in social-ecological systems. Ecology and Society 22(4):16. https://doi.org/10.5751/ES-09769-220416

Benneh, G. 1988. The land tenure and agrarian system in the new cocoa frontier of Ghana: Wassa Akropong case study. Pages 225-240 in W. Manshard, and W. B. Morgan, editors. Agricultural expansion and pioneer settlements in the humid tropics. University Press Japan, Tokyo, Japan.

Bezner Kerr, R., J. Kangmennaang, L. Dakishoni, H. NyantakyiFrimpong, E. Lupafya, L. Shumba, R. Msachi, G. O. Boateng, S. S. Snapp, A. Chitaya, E. Maona, T. Gondwe, P. Nkhonjera, and I. Luginaah. 2019. Participatory agroecological research on climate change adaptation improves smallholder farmer 
household food security and dietary diversity in Malawi. Agriculture, Ecosystems \& Environment 279:109-121. https://doi. org/10.1016/j.agee.2019.04.004

Bodin, Ö., S. M. Alexander, J. Baggio, M. L. Barnes, R. Berardo, G. S. Cumming, L. E. Dee, A. P. Fischer, M. Fischer, M. Mancilla Garcia, A. M. Guerrero, J. Hileman, K. Ingold, P. Matous, T. H. Morrison, J. Pittman, G. Robins, and J. S. Sayles. 2019. Improving network approaches to the study of complex social-ecological interdependencies. Nature Sustainability 2:551-559. https://doi. org/10.1038/s41893-019-0308-0

Bodin, Ö., and B. I. Crona. 2009. The role of social networks in natural resource governance: what relational patterns make a difference? Global Environmental Change 19(3):366-374. https:// doi.org/10.1016/j.gloenvcha.2009.05.002

Bonabana-Wabbi, J. 2002. Assessing factors affecting adoption of agricultural technologies: the case of integrated pest management (IPM) in Kumi District, Eastern Uganda. Dissertation. Virginia Polytechnic Institute and State University, Blacksburg, Virginia, USA.

Boon, E. K., and S. W. Anuga. 2019. Peasant organizations in Ghana: major players of sustainable development. Grain de Sel 78:21-22. [online] URL: https://www.inter-reseaux.org/en/ publication/n78-ghana-an-agricultural-exception-in-west-africa/peasantorganisations-in-ghana-major-players-of-sustainable-development/

Borden, K. A., L. C. N. Anglaaere, S. Owusu, A. R. Martin, S. W. Buchanan, S. Addo-Danso, and M. E. Isaac. 2020. Soil texture moderates key root functional traits in agroforestry systems across a climatic gradient. Agriculture, Ecosystems \& Environment 295:106915. https://doi.org/10.1016/j.agee.2020.106915

Borkhani, F. R., A. Rezvanfar, H. S. Fami, and M. Pouratashi. 2013. Social factors influencing adoption of integrated pest management (IPM) technologies by paddy farmers. International Journal of Agricultural Management and Development 3:211-218. [online] URL: http://ijamad.iaurasht.ac.ir/article_513909. $\underline{\mathrm{html}}$

Bunn, C., P. Läderach, A. Quaye, S. Muilerman, M. R. Noponen, and M. Lundy. 2019. Recommendation domains to scale out climate change adaptation in cocoa production in Ghana. Climate Services 16:100123. https://doi.org/10.1016/j.cliser.2019.100123

Burt, R. 2007. Secondhand brokerage: evidence on the importance of local structure for managers, bankers and analysts. Academy of Management Journal 50(1):119-148. https://doi. org/10.5465/amj.2007.24162082

Cadger, K., A. K. Quaicoo, E. Dawoe, and M. E. Isaac. 2016. Development interventions and agriculture adaptation: a social network analysis of farmer knowledge transfer in Ghana. Agriculture 6(3):32. https://doi.org/10.3390/agriculture6030032

Cook, B. R., P. Satizábal, and J. Curnow. 2021. Humanising agricultural extension: a review. World Development 140:105337. https://doi.org/10.1016/j.worlddev.2020.105337

Franzel, S., R. Coe, P. Cooper, F. Place, and S. J. Scherr. 2001. Assessing the adoption potential of agroforestry practices in subSaharan Africa. Agricultural Systems 69(1-2):37-62. https://doi. org/10.1016/S0308-521X(01)00017-8
Franzel, S. C., and S. J. Scherr. 2002. Introduction. Pages 1-10 in S. C. Franzel, and S. J. Scherr, editors. Trees on the farm: assessing the adoption potential of agroforestry practices in Africa. CABI, Wallingford, UK.

Gedikoglu, H., S. Tandogan, and J. Parcell. 2019. Neighbor effects on adoption of conservation practices: cases of grass filter systems and injecting manure. Annals of Regional Science (special issue paper). https://doi.org/10.1007/s00168-019-00963-6

Genius, M., P. Koundouri, C. Nauges, and V. Tzouvelekas. 2014. Information transmission in irrigation technology adoption and diffusion: social learning, extension services, and spatial effects. American Journal of Agricultural Economics 96(1):328-344. https://doi.org/10.1093/ajae/aat054

Ghana Cocoa Board. 2020. Ghana Cocoa and Forests Initiative national implementation plan (2018-2020). Republic of Ghana, Accra, Ghana. [online] URL: https://www.idhsustainabletrade. com/publication/cocoa-and-forests-initiatve-ghana-nationalimplementation-plan-2018-2020/

Heß, S., D. Jaimovich, and M. Schündeln. 2021. Development projects and economic networks: lessons from rural Gambia. Review of Economic Studies 88(3):1347-1384. https://10.1093/ $\underline{\text { restud } / \text { rdaa033 }}$

Isaac, M. E. 2012. Agricultural information exchange and organizational ties: the effect of network topology on managing agrodiversity. Agricultural Systems 109:9-15. https://doi. org/10.1016/j.agsy.2012.01.011

Isaac, M. E., L. C. Anglaaere, D. S. Akoto, and E. Dawoe. 2014. Migrant farmers as information brokers: agroecosystem management in the transition zone of Ghana. Ecology and Society 19(2):56. https://doi.org/10.5751/ES-06589-190256

Isaac, M. E., and K. A. Borden. 2019. Nutrient acquisition strategies in agroforestry systems. Plant and Soil 444:1-19. https:// doi.org/10.1007/s11104-019-04232-5

Isaac, M. E., B. H. Erickson, S. J. Quashie-Sam, and V. R. Timmer. 2007. Transfer of knowledge on agroforestry management practices: the structure of farmer advice networks. Ecology and Society 12(2):32. https://doi.org/10.5751/ES-02196-120232

Isaac, M. E., and P. Matous, 2017. Social network ties predict land use diversity and land use change: a case study in Ghana. Regional Environmental Change 17:1823-1833. https://doi. org/10.1007/s10113-017-1151-3

Isakson, R. 2014. Maize diversity and the political economy of agrarian restructuring in Guatemala. Journal of Agrarian Change 14(3):347-379. https://doi.org/10.1111/joac.12023

Joffre, O. M., P. M. Poortvliet, and L. Klerkx. 2019. To cluster or not to cluster farmers? Influences on network interactions, risk perceptions, and adoption of aquaculture practices. Agricultural Systems 173:151-160. https://doi.org/10.1016/j.agsy.2019.02.011

Kasanga, K., and N. A. Kotey. 2001. Land management in Ghana: building on tradition and modernity. Land Tenure and Resource Access in West Africa. International Institute for Environment and Development, London, UK. [online] URL: https://pubs.iied.org/9002iied 
Klerkx, L., N. Aarts, and C. Leeuwis. 2010. Adaptive management in agricultural innovation systems: the interactions between innovation networks and their environment. Agricultural Systems 103(6):390-400. https://doi.org/10.1016/j. agsy.2010.03.012

Klerkx, L., B. van Mierlo, and C. Leeuwis. 2012. Evolution of systems approaches to agricultural innovation: concepts, analysis and interventions. Pages 457-483 in I. Darnhofer, D. Gibbon, B. Dedieu, editors. Farming systems research into the 21st century: the new dynamic. Springer, Dordrecht, Netherlands.

Knudsen, M. H., and J. Agergaard. 2015. Ghana's cocoa frontier in transition: the role of migration and livelihood diversification. Geografiska Annaler: Series B, Human Geography 97 (4):325-342. https://doi.org/10.1111/geob.12084

Kozicka, M., E. Gotor, W. Ocimati, T. de Jager, E. Kikulwe, and J. C. J. Groota. 2020. Responding to future regime shifts with agrobiodiversity: a multi-level perspective on small-scale farming in Uganda. Agricultural Systems 183:102864 https://doi. org/10.1016/j.agsy.2020.102864

Kpienbaareh, D., R. Bezner Kerr, I. Luginaah, J. Wang, E. Lupafya, L. Dakishoni, and L. Shumba. 2020. Spatial and ecological farmer knowledge and decision-making about ecosystem services and biodiversity. Land 9(10):356. https://doi. org/10.3390/land9100356

Krishnan, P., and M. Patnam. 2012. Neighbours and extension agents in Ethiopia: who matters more for technology diffusion? IGC Working Paper No. 12/0159. International Growth Centre, London, UK. [online] URL: https://www.theigc.org/blog/ neighbours-and-extension-agents-in-ethiopia-who-matters-morefor-technology-diffusion/

Kroeger, A., H. Bakhtary, F. Haupt, and C. Streck. 2017. Eliminating deforestation from the cocoa supply chain. World Bank, Washington, D.C., USA. [online] URL: https:// openknowledge.worldbank.org/handle/10986/26549

Labeyrie, V., M. Antona, J. Baudry, D. Bazile, Ö. Bodin, S. Caillon, C. Leclerc, C. Le Page, S. Louafi, J. Mariel, F. Massol, and M. Thomas. 2021. Networking agrobiodiversity management to foster biodiversity-based agriculture: a review. Agronomy for Sustainable Development 41:4. [online] URL: https://agritrop. cirad.fr/597116/

Leeuwis, C., and N. Aarts. 2012. Rethinking communication in innovation processes: creating space for change in complex systems. Journal of Agricultural Education and Extension 17 (1):21-36. https://doi.org/10.1080/1389224X.2011.536344

Leitão, M. C. C. 2020. Shade trees, disease and cocoa production in Western Ghana: a case study. Dissertation. Wageningen University, Wageningen, The Netherlands. [online] URL: https:// bscmsc.pps.wur.nl/shade-trees-disease-and-cocoa-production-westernghana-case-study

Lescourret, F., D. Magda, G. Richard, A.-F. Adam-Blondon, M. Bardy, J. Baudry, I. Doussan, B. Dumont, F. Lefèvre, I. Litrico, R. Martin-Clouaire, B. Montuelle, S. Pellerin, M. Plantegenest, E. Tancoigne, A. Thomas, H. Guyomard, and J.-F. Soussana. 2015. A social-ecological approach to managing multiple agroecosystem services. Current Opinion in Environmental Sustainability 14:68-75. https://doi.org/10.1016/j.cosust.2015.04.001
Levy, M. A., and M. N. Lubell. 2018. Innovation, cooperation, and the structure of three regional sustainable agriculture networks in California. Regional Environmental Change 18:1235-1246. https://doi.org/10.1007/s10113-017-1258-6

Li, T. M. 2014. Land's end: capitalist relations on an indigenous frontier. Duke University Press, Durham, North Carolina, USA.

Matouš, P., Y. Todo, and D. Mojo. 2013. Roles of extension and ethno-religious networks in acceptance of resource-conserving agriculture among Ethiopian farmers. International Journal of Agricultural Sustainability 11:301-316. https://doi. org/10.1080/14735903.2012.751701

Matous, P., and P. Wang. 2019. External exposure, boundary spanning, and opinion leadership in remote communities: a network experiment. Social Networks 56:10-22. https://doi. org/10.1016/j.socnet.2018.08.002

Mortimore, M., and M. Tiffen. 2004. Introducing research into policy: lessons from district studies of dryland development in Sub-Saharan Africa. Development Policy Review 22(3):259-285. https://doi.org/10.1111/j.1467-7679.2004.00249.x

Nasser, F., V. A. Maguire-Rajpaul, W. K. Dumenu, and G. Y. Wong. 2020. Climate-smart cocoa in Ghana: how ecological modernisation discourse risks side-lining cocoa smallholders. Frontiers in Sustainable Food Systems 4:73. https://doi. org/10.3389/fsufs. 2020.00073

Norton, G. W., and J. Alwang. 2020. Changes in agricultural extension and implications for farmer adoption of new practices. Applied Economic Perspectives and Policy 42(1):8-20. https://doi. org/10.1002/aepp.13008

Nyantakyi-Frimpong, H., C. Hickey, E. Lupafya, L. Dakishoni, R. B. Kerr, I. Luginaah, and M. Katundu. 2017. A farmer-tofarmer agroecological approach to addressing food security in Malawi. Pages 121-138 in C. Anderson, C. Buchanan, M. Chang, J. Sanchez Rodriguez, T. Wakeford, editors. Everyday experts: how people's knowledge can transform the food system. Centre for Agroecology, Water and Resilience (CAWR), Coventry University, Coventry, UK. [online] URL: http://www.cenesta.org/ wp-content/uploads/2017/12/publication-everyday-experts-2017pkec-en.pdf

Nyantakyi-Frimpong, H., P. Matouš, and M. E. Isaac. 2019. Smallholder farmers' social networks and resource-conserving agriculture in Ghana. Ecology and Society 24(1):5. https://doi. org/10.5751/ES-10623-240105

Porter, G., and F. Lyon. 2006. Groups as a means or an end? Social capital and the promotion of cooperation in Ghana. Environment and Planning D: Society and Space 24(2):249-262. https://doi. org/10.1068/d0303

Rihoux, B. 2006. Qualitative comparative analysis (QCA) and related systematic comparative methods: recent advances and remaining challenges for social science research. International Sociology 21(5):679-706. https://doi.org/10.1177/0268580906067836

Rogers, E. M. 1995. Diffusion of innovations. Simon and Schuster, New York, New York, USA.

Sauvadet, M., R. Asare, and M. E. Isaac. 2020. Evolutionary distance explains shade tree selection in agroforestry systems. 
Agriculture, Ecosystems \& Environment 304:107125. https://doi. org/10.1016/j.agee.2020.107125

Stemerding, P., A. Musch, and Y. Diarra. 2002. Social dimensions of integrated production and pest management: a case study in Mali. Food and Agriculture Organization, Rome, Italy.

Takyi, S. A., O. Amponsah, D. K. Inkoom, and G. A. Azunre. 2019. Sustaining Ghana's cocoa sector through environmentally smart agricultural practices: an assessment of the environmental impacts of cocoa production in Ghana. Africa Review 11 (2):172-189. https://doi.org/10.1080/09744053.2019.1635416

Tamburini, G., R. Bommarco, T. C. Wanger, C. Kremen, M. G. A. van der Heijden, M. Liebman, and S. Hallin. 2020. Agricultural diversification promotes multiple ecosystem services without compromising yield. Science Advances 6(45):1-8. https://doi. org/10.1126/sciadv.aba1715

Tiffen, M., M. Mortimore, and F. Gichuki. 1994. More people, less erosion: environmental recovery in Kenya. John Wiley \& Sons, Hoboken, New Jersey, USA.

Tittonell, P., E. Scopel, N. Andrieu, H. Posthumus, P. Mapfumo, M. Corbeels, G. E. van Halsema, R. Lahmar, S. Lugandu, J. Rakotoarisoa, F. Mtambanengwe, B. Pound, R. Chikowo, K. Naudin, B. Triomphe, and S. Mkomwa. 2012. Agroecology-based aggradation-conservation agriculture (ABACO): targeting innovations to combat soil degradation and food insecurity in semi-arid Africa. Field Crops Research 132:168-174. https://doi. org/10.1016/j.fcr.2011.12.011

Tropenbos International Ghana. 2019. Drastic changes are needed in the cocoa sector to halt deforestation in Ghana. Policy brief. Tropenbos International Ghana, Wageningen, The Netherlands. [online] URL: https://www.tropenbos.org/resources/ publications/drastic+changes + are + needed + in + the + cocoa + sector + $\underline{\text { to }+ \text { halt }+ \text { deforestation }+ \text { in }+ \text { ghana }}$

Turner, S. 2012. "Forever Hmong": ethnic minority livelihoods and agrarian transition in upland Northern Vietnam. Professional Geographer 64(4):540-553. https://doi. org/10.1080/00330124.2011.611438

Vanlauwe, B., and K. E. Giller. 2006. Popular myths around soil fertility management in sub-Saharan Africa. Agriculture, Ecosystems \& Environment 116(1-2):34-46. https://doi. org/10.1016/j.agee.2006.03.016

Wang, G., Q. Lu, and S. C. Capareda. 2020. Social network and extension service in farmers' agricultural technology adoption efficiency. PLoS ONE 15(7):e0235927. https://doi.org/10.1371/ journal.pone. 0235927

Whitehead, A. 2002. Tracking livelihood change: theoretical, methodological and empirical perspectives from north-east Ghana. Journal of Southern African Studies 28(3):575-598. https://doi.org/10.1080/0305707022000006521

Wigboldus, S., L. Klerkx, C. Leeuwis, M. Schut, S. Muilerman, and H. Jochemsen. 2016. Systemic perspectives on scaling agricultural innovations: a review. Agronomy for Sustainable Development 36:46. https://doi.org/10.1007/s13593-016-0380-z 